\title{
Do Political Stability and Democracy Increase National Growth? Evidence from African Countries Using the GMM Method
}

\section{Nahed Zghidi*}

Department of Economics and Management, Higher Business School of Sfax, Tunisia

${ }^{*}$ Corresponding author: Nahed Z, Department of Economics and Management, Higher Business School of Sfax, Tunisia, Tel: +216 74 242 951 ; E-mail: nahed.zghidi@gmail.com

Receiving date: Mar 07, 2017, Accepted date: Mar 27, 2017, Published date: Mar 31, 2017

Copyright: (C) 2017 Nahed Z. This is an open-access article distributed under the terms of the Creative Commons Attribution License, which permits unrestricted use, distribution, and reproduction in any medium, provided the original author and source are credited.

\begin{abstract}
The objective of this paper is to examine the relationship between political stability, democracy, and economic growth for 31 African countries covering the 1986/2014 period. To achieve this goal, first, the impact of political stability on economic growth was first investigated. Second, the transmission channels between democracy and economic growth were described. Finally, through a panel estimation using the GMM method, the positive and statistically significant impact of democracy and political stability on these countries economic growth was confirmed.
\end{abstract}

Keywords: Economic growth; Political stability; Democracy; GMM

\section{Introduction}

Debates on development revolve around the role of the state and the market in economic and social growth. However, the failure of the market to bring about the scheduled development on the hand and the failure of the state to regulate the functioning of the whole economy led to the New Institutional Economics (NIE).

The role of institutions is increasingly referred to refs. [1-3], as a key for growth, mainly, in terms of property rights protection, regulatory structures, judiciary and bureaucratic competence quality and independence.

The political institutions quality is the foundation for a long run sustainable economic growth. According to North [1] "Third World countries are poor because the institutional constraints define a set of payoffs to political/economic activity, which do not encourage productive activity". As a consequence, the most stable countries are those that have more reliable, solid institutions capable of effectively managing conflicts between opposing groups. The efficient allocation of scarce resources, while taking into account the inter-temporal decisions, such as investment, savings, loan or research and development, requires efficient economic institutions that do not spontaneously arise from the rational individual interest.

The diversity of these types, as well as the efficiency degree of these institutions, are the product of the quality of the political institutions. These are rather determinants of the quality of economic institutions; they identify the economic institutions 'production' process and play a key role in setting up and preserving the property rights. Adam Smith recognized the importance of the property rights for the markets and exchanges functioning. The political stability has to be studied in an institutional setting as it sometimes results from the institutional robustness. Azam et al. [4] showed that political instability might be clearly noticed in nondemocratic regimes rather than in democratic ones. A democratic regime can, thus, reduce the instability risk.

Moreover, democracy is likely to have a positive impact on school attendance rates. Saint-Paul and Verdier [5] affirm that, if democracy gave more importance to the needs of the population than dictatorship, it should facilitate the implementation of education policies. In this way, democracy will be an additional factor of the individuals' emancipation. Furthermore, education could be regarded as a direct contributor to economic growth. Adopting democracy also constitutes an egalitarian standpoint which facilitates access to the decision of the poorest social classes and causes some kind of income redistribution within the economy. Moreover, it seems that the income inequality and economic growth are negatively correlated Alesina and Perotti [6], therefore, through this channel, democracy should once again positively affect economic growth.

The political instability is the greatest challenge for the African governments and peoples. In terms of stability, many African countries are poorly ranked. This continent is hit by several types of political instability such as revolutionary movements to change the political game rules and redistribute power and property, separatist movements, political assassinations, murders, extortion and violence, strikes, especially the politically motivated ones, complete political breakdown and civil wars. The main causes that underlie this instability are ethnicity and/or historical frictions; secessionist impulses; conflicts over wealth resources; ineffective or predatory governmental interventions; political inexperience and aggravated economic difficulties.

Such instability in Africa explains, delineates the reason(s) for this continent to lag far behind other world regions in terms of economic development. That is why the political institutions need to be developed so as to establish a common understanding ground and accountability.

\section{Political Stability Impact on Economic Growth}

\section{An economic analysis of political institutions}

The political institutions quality is exclusively measured the uncertainty or instability of these institutions themselves. This can help avoid the comparative advantages controversy over the democratic and autocratic institutions in terms of economic efficiency. 
North [1] states that: "The major role of institutions in a society is to reduce uncertainty by establishing a stable (but not necessarily efficient) structure to human interaction. The overall stability of an institutional framework makes the complex exchange possible across both time and space (...). This set of stability features in no way guarantees that the institutions relied upon are efficient, although stability may be a necessary condition for human interaction, but it is not certainly a sufficient condition for efficiency."

The political stability requires that the public freely interact with legislators on a regular basis. A stable political scene is that when a government leader is favored by the people but does not know the solid indicators of social unrest.

Political stability and economic development are closely linked. The relationship between economic growth and stability refers to the way political stability of a nation can lead to economic growth. The common denominator is the fact that a stable environment promotes economic growth.

One of the illustrations indicating how economic growth is tightly tied to political stability is the field of investment. In fact, no local or international company would feel at ease to make any kind of investment in any country where the political climate is characterized by constant change and considerable uncertainty [7].

For local businesses, investing in equipment, research \& development and human resources, including the recruitment of new permanent employees is achieved over the long run. Therefore, the institutions and policy forecasts have an impact on the management decisions of these investments. As policy uncertainties raise the expectations to invest and consume until it is resolved, the companies become more cautious and impede investment and consumption. Uncertainty about the different institutions, including the labor market, the environmental regulations and the electricity market, has similar effects on investment. This will affect the economic cycles over the short and long run economic growth [4].

Foreign direct investment plays an important role in the development of the economy. This shows that there is a relationship between economic growth and stability, since a low-ranked country, in terms of stability, will not attract investors who seek stable international markets to invest in. The field of tourism can be taken as the best illustration, because a lack of economic stability will decrease investment in hotels, in touristic attractions and commercial airliners (for example, the Tunisian and Egyptian cases in the recent years). This results in a reduction of the number of employed people and a lower turnover rate for finance which is much needed to facilitate economic development [8].

Barro [9] showed that the used variables to measure political instability, such as the number of revolutions and political assassinations, negatively affect both economic growth and investment.

The existing empirical studies have rarely focused on the endogenous aspect of the policy variables. However, if this possibility was taken into account, it would be studied through the impact of economic factors on the institutional sphere.

Gyimah-Brempong and Traynor [10] explored the relationship between political instability and economic growth in the developing countries. They used a model of simultaneous equations, a dynamic estimation of the panel and a wider measure of political instability to study the above mentioned relationship through the investment channel in the sub-Saharan African countries. Their results show that there is a two-way causal relationship between political instability and economic growth.

Fosu [7] defined the concept of the elites' instability as well as other less dramatic events related to social unrest (demonstrations, political violence). The availability of data allowed this article to primarily discuss a second meaning of the concept of political instability. The negative correlation between political instability and growth can be explained by the accumulation and efficiency of production factors.

Regarding the transmission channels, one may wonder about the fact that political instability directly or indirectly affects growth due to the efficiency of the production factors and the establishment of a favorable business environment. The inconclusive impact of democracy on growth tends towards an indirect influence, as highlighted by Tavares and Wacziarg [11]. These authors then turn to more complex models, such as that of Barro [9] with a single specification equation, to justify the interconnection between the economy and the political sphere. To this end, they systematically instructed nine channels through which they believe that democracy can affect growth, using a model with simultaneous equations. Two channels emerged as very influential: the accumulation of human capital and political stability.

\section{Democracy as an explanatory variable of economic growth}

According to Tavares and Wacziarg [11], democracy can be identified as a set of rules and procedures that regulate the transfer of political power and the free expression of disagreement at all levels of the public life. The relationship between democracy and economic development is the subject of a vast literature in both politics and economics. Theoretically, the relationship is ambiguous.

In economics [12,13], among others, argue that democracies engage in an improper redistribution (e.g., the average median voter), which could discourage economic growth. Audaciously, Barro [14] further confirms this view: "More political rights do not-have an effect on growth". On the other hand, Olson [15], however, stresses the possibility of a political stalemate in democracy and suggests that the policy of interest groups in democracy may lead to stagnation.

Various studies showed that political democracy has enormous indirect effects on economic growth through capital accumulation, income distribution, economic freedom and political stability [16-19]. Therefore, considering the question of democracy and growth, it is worth reminding the broader associations which include the channels, or the indirect effects, between democracy and economic growth rather than the causality relationship between the political system and economic growth.

In the common use, capital implies a substitutable resource that can build up over time and promise higher returns in the future. Nowadays, an investment should bring a higher return at a later date. If a democratic system continues to exist, we believe it is likely to promote four types of capital: physical, human, social and political. The existing studies indicate that the four types of capital have positive effects on economic growth. As a consequence, we expect that the more democratic a country is, the greater its physical, human, social and political capital will be and the better the economic growth performance it will achieve.

The extent to which physical capital is equally distributed throughout the society is commonly regarded as an important component of economic growth in the long-run [20-22]. When 
democracy succeeds in redistributing wealth-through progressive taxation, social policy, land redistribution or simply opening markets and institutions of civil society to previously excluded groups, it seems reasonable to expect that the longer such a regime remains in power, the greater its overall effect on achieving social equality and therefore on growth will be [23,24]. In fact, there is evidence of a "Kuznets political curve" in which the immediate effect of democracy is to raise inequality while the long-run effect is to reduce it [25].

Therefore, even though the short-run effects of democracy are ambiguous s, theory and research suggest that a longer democratic experience should have a positive impact on wealth and income distribution in a society $[11,26]$. The role of the human capital identified by the endogenous growth theory can also be assumed as a strong impact on economic growth performance [14]. It seems possible to consider democracy as an important institutional factor in the development of human capital, widely measured by the improvement of education, public health and life expectancy. The political elites of a democracy have electoral incentives to improve the quality of life of the less privileged.

Such incentives do not exist or barely do in the authoritarian political regimes. Several studies showed that the democratic rule results in the improvement of the human capital resources of a society [17]. Due to the nature of the long-run human capital, the longer a democracy is settled, the more important the expected impact on the human capital will be [27]. Finally, a great number of economists argued that social capital also contributes to the economic productivity of a society. For instance, in a recent study, Guiso et al. [28] showed that social capital enhances financial development (which, in turn, is generally regarded as growth stimulant). If democracy contributes to the social capital development; it goes without saying that democracy would have a significant impact on the social capital development in the long-run. Once again, these observations suggest that the impact of democracy on economic growth can become obvious over time, if ever the social capital stock of a country grows (Figure 1).

In addition to the physical, human and social capital, we firmly believe that the established democracies create some kind of an explicit political capital. Just like the case of a delayed consumption that generates physical capital, which in turn, contributes to production, the current political experience of a country affects its future political capital and therefore its economic output.

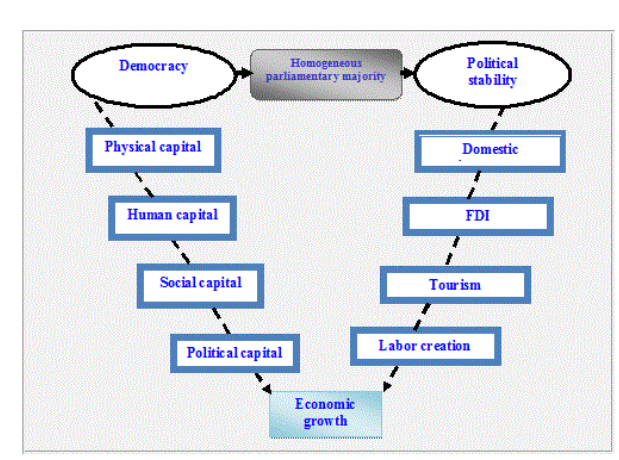

Figure 1: The relationship between political stability, democracy and economic growth.
Bhagwati and Rodrik $[29,30]$ emphasize that democracies provide a better economic growth quality through various means. Rodrik [30] highlights that: "participatory democracies allow better quality of growth by allowing greater predictability and stability in the long term, while being stronger in front of external shocks and providing better distributional results. The democratic institutions would help markets to work "perfectly", as assumed in the neoclassical economic models. An extension of these arguments lies in the "volatility" channel that has also proven to be an important indirect effect of democracy on economic growth. Sah [31] also argued that the authoritarian regimes have a more volatile performance than democracies. On the other hand, the non-democratic regimes are not a homogeneous batch $[6,16,19]$ whereas democracies are more homogeneous and can ensure a stable economic progress. Such a notion also implies less volatile long-run economic progress. Quinn and Woolley [32] have also referred to this endogeneity between economic growth and volatility. Democracy is also a component of the broader set of "inclusive political institutions", which is assumed by Acemoglu et al. [33] to be suitable for economic growth.

\section{Empirical Analysis}

The objective of this section was to empirically show the effect of democracy on both economic growth and political instability in some African countries. This econometric analysis was applied to the data involving multi-country and multi-period samples. We walked in the steps of the largest part of the empirical literature on endogenous growth, seeking to link the rate of a country's economic growth to the economic, political and social variables using a large sample of countries and periods. The estimated model was used to project the change of the growth rate for these countries and then examine whether its performance has been close to the expected values.

\section{Sample and regression specification}

Our sample includes 31 African countries (Algeria, Angola, Botswana, Burkina Faso, Cameroun, Congo Democratic Republic, Congo, Cote d'Ivoire, Egypt, Ethiopia, Gabon, Gambia, Ghana, Guinea, Kenya, Madagascar, Malawi, Mali, Morocco, Mozambique, Namibia, Niger, Nigeria, Senegal, Sierra Leone, Soudan, South Africa, Togo, Tunisia, Zambia, Zimbabwe) covers annual data over the 1986-2014 period.

The basic regression equation to be estimated is the following:

$$
y_{\text {it }}-y_{\text {it- } 1}=\alpha y_{\text {it }-1}+\beta X_{\text {it }}+I V_{\text {it }}+\mu_{\mathrm{i}}+\varepsilon_{\text {it }}(1)
$$

Where indices $\mathrm{i}$ and $\mathrm{t}$ represent the country and the period, respectively; $\mathrm{y}$ is the logarithm of the per capita GDP, $\mathrm{X}$ is a set of the control variables, and IV represents both of the (political stability and democracy) institutional variables; $\mu_{\mathrm{i}}$ is the individual heterogeneity with $\left(\mu \sim\right.$ i.i.d. $\left.\left(0, \sigma_{2 \mu}\right)\right)$; and $\varepsilon_{\text {it }}$ is the regression residue.

Just as in the literature, the dependent variable is the average growth rate of the real per capita GDP (i.e., the logarithmic difference of the per capita GDP standardized by the length of the period). The equation to be regressed is dynamic insofar as it includes the initial level of the per capita GDP as an explanatory variable. Our measures of political stability and of democracy are given by the ICRG database, "Political Risk Rating" and "Democratic Accountability", respectively. The set of the control variables includes variables that vary over time and from one country to another. 
Page 4 of 5

The per capita production (in log) level at the beginning of the period (to take into account the conditional convergence), the average rate of tertiary education corresponds to the investment in the human capital. The state total expenses respond to the tax policy and the commercial openness measured by the ratio of the exports and the real imports to the real GDP and the stock of the per capita physical capital. The volume of the physical capital stock is measured using the study of Van Pottelsberghe [34].

The physical capital stock ' $\mathrm{K}$ ' of year " $\mathrm{t}$ " is equal to its stock in "t-1"leveled to a depreciation rate by adding the investment level ' $I$ ' at time " $\mathrm{t}$ ": $\mathrm{K}_{\mathrm{t}}=\mathrm{I}_{\mathrm{t}}+(1-\delta) \mathrm{K}_{\mathrm{t}-1}$, with It: the real gross fixed capital formation and $\delta$ : the capital depreciation rate $(\delta=6 \%)$.

The physical capital initial stock ' $\mathrm{KO}$ ' is equal to the initial investment ' 10 ' divided by the sum of the annual growth rate of the It investment and the rate of physical capital depreciation $\delta: K_{0}=I_{0} /(\varphi+\delta)$. The per capita physical capital stock is given by dividing the calculated physical capital stock by the total population.

\section{The estimation methodology}

This study used the Generalized Method of Moments (GMM) developed for the dynamic panel data models introduced [35-37]. This method is based on differentiation regressions or the non-observed effect control instruments, on the one hand, and the use of the previous instruments of the explanatory and delayed variables as instruments (called internal instruments), on the other hand.

Relying on the model of Mankiew et al. [38], expanded by several authors during the 1990s, is justified by two major arguments. Firstly, it has been widely used by recent empirical studies on the determinants of the economic growth rate, hence its reliability. Secondly, it enables us to examine the effects of the interesting variables while taking into account the impact of other control variables identifying the growth of the per capita GDP.

The forthcoming estimates will be based on the following two functions: (2)

$$
g r_{\text {it }}=\alpha+\beta_{1} \text { gdp }_{\text {it }-1}+\beta_{2} \mathrm{ps}_{\text {it }}+\beta_{3} \mathrm{cap}_{\text {it }}+\beta_{4} \mathrm{tedu}_{\text {it }}+\beta_{5} \mathrm{~g}_{\mathrm{it}}+\beta_{6} \mathrm{open}_{\text {it }}+\varepsilon_{\text {it }}
$$

$$
g r_{\text {it }}=\alpha+\beta_{1} \text { gdp }_{\text {it }-1}+\beta_{2} \text { dem }_{\text {it }}+\beta_{3} \text { cap }_{\text {it }}+\beta_{4} \text { tedu }_{\text {it }}+\beta_{5} \mathrm{~g}_{\text {it }}+\beta_{6} \text { open }_{\text {it }}+
$$
$\varepsilon_{\text {it }}(3)$

with $\mathrm{i}$ indicating the countries $(\mathrm{i}=1,2, \ldots, \mathrm{N})$ and $\mathrm{t}$ is the time $(\mathrm{t}=1$, ..., T); $\$)$;

$g r$ The average annual growth rate of the per capita real GDP (in US $g d p-1$ : The initial real per capita GDP (in US \$);

psa: Proxy measuring political stability (Political Risk Rating);

dem: A proxy measuring democracy (Democratic Accountability);

cap: The capital per head;

tedu: The tertiary schooling rate;

$g$. The ratio of public consumption in relation to the GDP;

open: The ratio of the sum of exports and imports to the GDP;

sit: The error term.
All these variables were adopted from the annual data of the World Bank database (WDI, 2016), while the institutional data were collected from the ICRG database (2015).

The regressions of equations (2) and (3) led us to the results presented in Table 1.

This table shows that the variables estimated coefficients have the expected signs and are statistically significant. It is clear that, in both equations, the coefficient of the real initial per capita GDP variable is statistically significant with a negative sign. This confirms Solow's economic theory of conditional convergence according to which countries with low per capita incomes have higher growth rates than

\begin{tabular}{|c|c|c|}
\hline & Equation 1 & Equation 2 \\
\hline pibt $_{-1}$ & $-0.235^{\star * *}$ & $-0.245^{\star \star *}$ \\
\hline cap & $0.0744^{* * *}$ & $0.0845^{\star \star \star}$ \\
\hline tedu & $0.0373^{\star *}$ & $0.0299^{* *}$ \\
\hline g & $-0.0684^{\star \star *}$ & $-0.0625^{\star \star \star}$ \\
\hline ouv & $0.172^{\star \star \star}$ & $0.175^{\star \star \star}$ \\
\hline $\mathrm{sp}$ & $0.0588^{* * *}$ & \\
\hline dem & & $0.00551^{* * *}$ \\
\hline c & $0.151^{\star \star *}$ & $0.226^{* \star *}$ \\
\hline $\mathrm{N}$ & 866 & 416 \\
\hline Number of instruments & 61 & 61 \\
\hline Sargan's test & 26.030 & 26.475 \\
\hline
\end{tabular}
those of the richest countries.

Table 1: The regressions results using the GMM: Endogenous variable (gr).

The sign of the education variable, identifying the role of the human capital quality, is positive and identical to the expected sign. It can be deduced that the human capital indicator has a positive impact on economic growth, which confirms the important role of education as a driver of economic development (in accordance with Lukas's hypotheses). In fact, an increase of the human capital accumulation rate by $1 \%$ is reflected by a rise of the per capita GDP growth rate by about $0.03 \%$.

The results also reveal that a $1 \%$ increase of political stability by implies a rise of the per capita GDP growth by $0.058 \%$, which is consistent with the expected results. The various analyses on the relationship between political stability and growth performance forward the existence of a stable government as a necessary condition for a sustained long-run growth.

Political stability is a necessary condition for the macroeconomic stability that allows a full exploitation of the long-run potential growth. Similarly, the democracy coefficient indicates that democratization will bring along an increase of the per capita GDP by $0.005 \%$. This result is consistent with the study of Barro [14] who considers democratization 
an important mechanism by which public participation can foster economic development.

The negative and statistically significant sign of the "public expenses" variable in a percentage of GDP is expected owing to the non-productive role of these expenses in the developing countries. The importance of the negative effect of Government spending is around $6.8 \%$.

The regressions indicate that the openness policy has a positive effect on economic growth. This result may lead us to assume that the reduction of restrictions on foreign trade has a positive effect on economic growth. Therefore, a $1 \%$ increase of the openness ratio would lead to around $0.17 \%$ increase of the real GDP.

\section{Conclusion}

This study has taken a further step in clarifying the effect of political stability and democracy on economic growth for the developing countries. It first investigated the role of political stability in enhancing the economic development. In the second step, it tried to find out the way the democratization of the developing countries can have an impact on the improvement of economic growth. Finally, after having theoretically identified the impact of both political stability and democracy, we assessed their effect on the growth of the African countries by applying the GMM method of Arellano [36] for a dynamic panel. These instrumental variables were proven to have a positive impact on the economic development degree [39].

\section{References}

1. North D (1990) Institutions, Institutional Change and Economic Performance. Cambridge University Press, New York.

2. Rodrik D (1999) Democracies pay higher wages. Quarterly Journal of Economics 114: 707-738.

3. Easterly W, Levine R (1997) Africa's growth tragedy: policies and ethnic division. Quarterly Journal of Economics 112: 1203-1250.

4. Azam JP, Berthelemy JC, Calipel S (1996) Risque politique et croissance en Afrique. Revue Economique 47: 819-829

5. Saint-Paul G, Verdier T (1993) Education, Democracy and Growth. Journal of Development Economics 42: 399-407.

6. Alesina A, Perotti R (1994) The Political Economy of Growth: A Critical Survey of the Recent Literature. The World Bank Economic Review 8: 351-371.

7. Fosu AK (2002) Political Instability and Economic Growth: Implication of Coup Events in Sub-Saharan Africa. American Journal of Economics and Sociology 61: 329-348.

8. Anderson J, Marcouiller D (2005) Anarchy and autarky: endogenous predation as a barrier to trade. International Economic Review 46: 189-213.

9. Barro RJ (1991) Economic growth in a cross section of countries. Quarterly Journal of Economics 106: 407-443.

10. Gyimah-Brempong K, Traynor TL (1999) Political Instability, Investment and Economic Growth in Sub-Saharan Africa. Journal of African Economies 8: 52-86.

11. Tavares J, Wacziarg R (2001) How Democracy Affects Growth. European Economic Review 45: 1341-1378.

12. Alesina A, Rodrik D (1994) Distributive Politics and Economic Growth. Quarterly Journal of Economic 109: 465-490.

13. Persson T, Tabellini G (1994) Is Inequality Harmful for Growth? American Economic Review 84: 600-621.
14. Barro RJ (1997) Determinants of Economic Growth: A Cross-Country Empirical Study. The MIT Press, Cambridge, Massachusetts.

15. Olson M (1982) The Rise and Decline of Nations. Yale University Press, New Haven.

16. Alesina A, Ozler S, Roubini N, Swagel P (1996) Political Instability and Economic Growth. American Economic Review 98: 808-842.

17. Baum MA, Lake DA (2003) The Political Economy of Growth: Democracy and Human Capital. American Journal of Political Science 47: 333-347.

18. Sturm JE, Haan J (2001) How Robust Is the Relationship between Economic Freedom and Economic Growth?. Applied Economics 33: 839-844.

19. De Haan J, Siermann CLJ (1996) New Evidence on the Relationship between Democracy and Economic Growth. Public Choice 86: 175-198.

20. Besley T, Burgess R (2000) Land Reform, Poverty Reduction and Growth: Evidence from India. Quarterly Journal of Economics 115: 389-430.

21. Sokoloff KL, Engerman SL (2000) Institutions, Factor Endowments, and Paths of Development in the New World. Journal of Economic Perspectives 14: 217-232.

22. Forbes K. (2000) A Reassessment of the Relationship between Inequality and Growth. American Economic Review 90: 869-887.

23. Meltzer AH, Richard SF (1981) A Rational Theory of the Size of Government. Journal of Political Economy 89: 914-927.

24. Muller EN (1988) Democracy, Economic Development, and Income Inequality. American Sociological Review 53: 50-68.

25. Chong A (2004) Inequality, Democracy, and Persistence: Is There a Political Kuznets Curve? Economics and Politics 16: 189-212.

26. Gradstein M, Milanovic B (2004) Does Liberte=Egalite? A Survey of the Empirical Links between Democracy and Inequality with Some Evidence on the Transition Economies. Journal of Economic Surveys 18: 515-537.

27. Gerring J, Thacker S, Alfaro R (2005) Democracy and Human Development. Annual meeting of the American Political Science Association, Washington, D.C.

28. Guiso L, Sapienza P, Zingales L (2004) The Role of Social Capital in Financial Development. American Economic Review 94: 526-556.

29. Bhagwati J (1995) Democracy and Development: New Thinking on an Old Question. Indian Economic Review 30: 1-18.

30. Rodrik D (2000) Institutions for High-Quality Growth: What They Are and How to Acquire Them. Studies in International Comparative Development 35: 3-31.

31. Sah RK (1991) Fallibility in Human Organizations and Political Systems. Journal of Economic Perspectives 5: 67-88.

32. Quinn DP, Woolley JT (2001) Democracy and National Economic Performance: The Preference for Stability. American Journal of Political Science 45: 634-657.

33. Acemoglu D, Johnson S, Robinson J, Yared P (2008) Income and Democracy. Journal of Economic Growth 1: 189-211.

34. Van Pottelsberghe DPB (1997) Issues in assessing the effect of interindustry R\&D spillovers. Economic Systems Research 9: 331-356.

35. Holtz-Eakin D, Newey W, Rosen HS (1988) Estimating Vector Autoregressions with Panel Data. Econometrica 56: 1371-1395.

36. Arellano M, Bond S (1991) Some Tests of Specification for Panel Data: Monte Carlo Evidence and an Application to Employment Equations. The Review of Economic Studies 58: 277-297.

37. Arellano M, Bover O (1995) Another look at the instrumental variable estimation of error-components models. Journal of Econometrics 68 29-51.

38. Mankiew NG, Romer, Weil DN (1992) A Contribution to the Empirics of Economic Growth. The Quarterly Journal of Economics 407-437.

39. Tavares J, Wacziarg R (1996) How Democracy Fosters Growth. 